\title{
MENGATUR KELAHIRAN DALAM PERSPEKTIF MORAL KATOLIK
}

\author{
Yohanes Sudaryanto
}

\begin{abstract}
:
The Church believes that God calls human to become partner in the work of creation. He gives sex to human as a mean of the plan. Contraception is an instrument used by human for birth control. The Church, with her moral teachings doesn't forbid Catholic couples to control births, but she wants them to use the methods are that morally good. The study aims to determine the things that underlie Catholic couples in the Parish of St. Yusuf Pekerja Gondangwinangun Klaten in choosing specific ways to regulate births. To collect the data, the author used questionnaires to all respondents and in depth interviews to some of the respondents. The results indicated that the majority of Catholic couples use contraception to regulate births in their family. There are several factors that influence this practices. The main factor is their lack of complete knowledge about contraception and the Church's teaching about it. Based on the data, the author proposes some pastoral suggestions for the Church in order to guide the Catholic couple to regulate births. Delivering the Church's teaching on birth control is one form of responsibility of parish priests to keep the values of the Catholic marriage.
\end{abstract}

\section{Kata-kata kunci:}

Ajaran Moral Gereja, perkawinan, pengaturan kelahiran, kontrasepsi, metode alamiah.

\section{PENDAHULUAN}

\section{Latar Belakang Masalah}

Konsili Vatikan II (1962-1965) membawa pembaruan yang begitu besar dalam Gereja. Beberapa sikap diambil oleh konsili terhadap masyarakat dan dunia. Masalahmasalah yang dulu dianggap peka dapat dengan terus terang dibicarakan. Salah satunya adalah tentang pengaturan kelahiran dengan kontrasepsi dalam perkawinan.

Paus Yohanes XXIII membentuk sebuah "Komisi kepausan untuk studi mengenai masalah-masalah keluarga, kependudukan dan kelahiran" pada bulan Maret 1963, dengan anggota 6 orang ahli: 3 orang teolog dan 3 orang ilmuwan. Setelah Paus
Yohanes XXIII wafat, Paus Paulus VI pada tahun 1964 memperluas jumlah anggota komisi itu menjadi 70 orang yang terdiri dari awam, para ahli kependudukan, dokter, para ahli ilmu sosial, bapak-ibu keluarga, imam, uskup dan kardinal.

Pada tahun 1966 komisi itu tidak mencapai kesepakatan mengenai moralitas kontrasepsi dan menyerahkan kepada Paus dua saran yang berbeda. Mayoritas anggota komisi menyarankan diadakan perubahan terhadap ajaran mengenai kontrasepsi, sedangkan minoritas anggota komisi menyarankan supaya mempertahankan ajaran tradisional yang melarang segala macam kontrasepsi. Menanggapi dua saran itu, Paus Paulus VI menerbitkan ensiklik "Humanae Vitae" pada tanggal 25 Juli 1968 
yang berbicara mengenai pengaturan kelahiran (On the Regulation of Birth) yang melarang pengaturan kelahiran dengan menggunakan alat-alat kontrasepsi.

Masih banyak pasangan suami-isteri Katolik yang belum memahami ajaran moral Gereja mengenai pengaturan kelahiran. Mereka menggunakan alat-alat kontrasepsi yang banyak tersedia di tengah masyarakat untuk mengatur kelahiran. Gereja mendukung keluarga berencana (KB) dalam arti luas, yakni keluarga yang bertanggung jawab. ${ }^{1}$ Gereja mengajak setiap pasangan suami-isteri Katolik untuk ber-KB secara benar, secara bertanggung jawab, yang "direncanakan" bukan sebatas "jumlah anak" dalam keluarga melainkan semua aspek dalam kehidupan berkeluarga.

\section{Rumusan Masalah}

Gereja sudah memberikan pedoman moral bagi pasangan suami-isteri Katolik dalam hal keluarga berencana (keluarga yang bertanggungjawab), tetapi umat belum dapat sepenuhnya mewujudkan apa yang diharapkan oleh Gereja. Masih banyak pasangan suami-isteri yang menggunakan kontrasepsi untuk membatasi kelahiran anak dalam keluarga mereka. Apakah umat tidak tahu bahwa Gereja sudah memberikan ajaran-ajaran moral terkait dengan pengaturan kelahiran (keluarga berencana)?

Pasangan suami-isteri Katolik berada di tiga kemungkinan. 1) Mereka memahami makna keluarga berencana yang dimaksudkan oleh Gereja dan telah berusaha mewujudkannya dalam kehidupan mereka. 2) Mereka tidak memahami konsep keluarga berencana sebagaimana dimaksudkan oleh Gereja, sehingga mereka mencari cara yang praktis dan mudah untuk mengatur kelahiran anak dalam keluarga mereka. Karena mereka tidak mengakses kebijakankebijakan Gereja atau karena pihak Gereja tidak menyampaikan kepada mereka kebijakan-kebijakan tersebut, maka mereka menggunakan cara-cara yang dicanangkan oleh pemerintah. 3) Mereka tahu dan paham ajaran Gereja mengenai pengaturan kelahiran namun tidak mempraktikkannya.
Beberapa pertanyaan muncul berkaitan dengan praktik kontrasepsi di antara pasangan suami-isteri tersebut. 1) Apakah mereka yang menggunakan alat-alat kontrasepsi itu secara moral (moral Gereja) dapat dinilai buruk? 2) Bagaimana Gereja menyikapi persoalan ini? 3) Sejauh mana ajaran Gereja yang berhubungan dengan kontrasepsi memiliki kekuatan? Baik Gereja maupun pasangan suami-isteri mengalami situasi yang sulit.

\section{Tujuan dan Manfaat Penulisan}

Tulisan ini dimaksudkan untuk meneliti masalah-masalah moral yang terkait dengan penggunaan metode-metode kontrasepsi di kalangan umat Katolik di Paroki St. Yusuf Pekerja Gondangwinangun, Klaten. Sejauh mana umat beriman Katolik, terutama pasangan suami-isteri Katolik di Paroki St. Yusuf Pekerja Gondangwinangun Klaten ${ }^{2}$, memahami penilaian moral Gereja atas penggunaan alat-alat kontrasepsi. Tulisan ini diharapkan bisa memberikan pemahaman moral yang tepat kepada pasangan suami-isteri Katolik, secara khusus yang berkaitan dengan pandangan Gereja mengenai kontrasepsi.

Dengan demikian tulisan ini bisa bermanfaat bagi Gereja sebagai sebuah sumbangan pemikiran dalam karya pastoral, secara khusus pastoral keluarga dan membantu pasangan-pasangan suamiisteri Katolik dalam mengambil keputusan untuk mengatur kelahiran dalam keluarga agar sesuai dengan ajaran moral Gereja Katolik.

\section{Metode Penulisan}

Untuk memperoleh informasi mengenai ajaran Gereja tentang pengaturan kelahiran, penulis mencari data pustaka yang diperlukan yaitu bahan-bahan yang sudah dipublikasikan oleh Gereja, melalui bukubuku, artikel, serta tulisan-tulisan yang diakui oleh otoritas Gereja berkaitan dengan persoalan kontrasepsi. Selanjutnya dilakukan analisa, sejauh diperlukan, untuk menunjukkan sikap Gereja berkaitan dengan moralitas kontrasepsi.

Untuk mendapatkan data mengenai praktik pengaturan kelahiran dilakukan 
penelitian menggunakan metode penelitian lapangan, yaitu dengan memberikan kuisioner kepada 60 pasangan suami-isteri yang menjadi responden dan memperdalamnya melalui deep interview kepada sebagian responden. Responden adalah pasangan suami-isteri di Paroki St. Yusuf Pekerja Gondangwinangun, Klaten.

Responden terbagi dalam dua kategori, yaitu: usia perkawinan responden tingkat pendidikan. Kategori usia perkawinan responden dibagi dua kelompok, yaitu: usia perkawinan $\leq 20$ tahun dan $\geq 21$ tahun. Kategori tingkat pendidikan responden terdiri dari enam kelompok, yaitu: 1) SD, 2) SLTP, 3) SLTA/SMK, 4) Diploma dan Sarjana S1, 5) Pascasarjana, dan 6) Tidak Sekolah. Penulis ingin mengetahui apakah usia perkawinan dan tingkat pendidikan responden mempengaruhi praksis mereka dalam menggunakan alat kontrasepsi. Asumsinya ialah bahwa lamanya perkawinan serta tingginya tingkat pendidikan responden memberikan pengaruh pada penggunaan alat kontrasepsi untuk mengatur jumlah kelahiran anak.

Dengan menggunakan data yang ada, penulis menganalisa adanya kesenjangan antara ajaran Gereja mengenai kontrasepsi dan praksis umat. Hal itu dimaksudkan untuk menemukan alasan-alasan mendasar mengapa umat menggunakan kontrasepsi dalam mengatur kelahiran. Penulis ingin mengetahui bagaimana umat memahami ajaran moral Gereja mengenai kontrasepsi dan mengaktualkan dalam kehidupan perkawinan yang mereka jalani.

\section{PERKAWINAN DALAM PERSPEKTIF KATOLIK}

Tema pengaturan kelahiran yang dimaksudkan dalam tulisan ini adalah dalam konteks perkawinan. Oleh karenanya pertama-tama kita akan melihat perkawinan dalam pemahaman Gereja Katolik.

\section{Sakramentalitas Perkawinan}

Generasi pertama kekristenan mendasarkan pandangannya mengenai perkawinan pada Perjanjian Baru dan ajaran Paulus. ${ }^{3}$ Dalam hal ini, Groenen memberi keterangan bahwa ada pandangan yang mendua. Di satu pihak menganggap perkawinan itu baik sebagai sarana mewujudkan hadirnya Kerajaan Allah dan ethos Kristen (1Tim 4:4; 1Kor 7:38; 1Tim 4:3; 1Tim 4:1), di lain pihak perkawinan dilihat sebagai nilai duniawi belaka (1Tim 5:11,13-14; 1Tes 4:3-6; 1Kor 7:2,6-7,9). Pendirian yang paling positif dan idealistis terungkap dalam Efesus (Ef 5:25-33). Secara umum bisa dikatakan bahwa pada masa awal kekristenan pandangan tentang perkawinan belum memiliki tolok ukur yang mantap dan sama untuk semua.

Sikap yang secara negatif menilai perkawinan juga muncul pada abad II. Ada anggapan bahwa seks yang disalurkan dalam perkawinan seolah-olah begitu dilegitimasikan. Bahkan ada aliran yang secara blak-blakan menolak perkawinan (karena seksualitas), yang dinilai jahat. Tokoh yang paling terkenal dalam hal ini adalah Markion. ${ }^{4}$

Mulai abad V kekuasaan Gereja atas perkawinan umat beriman mulai terlihat ${ }^{5}$, dan semakin bertambah jelas pada abad XI - XII. Pembaruan yang dimulai oleh Gregorius VII menciptakan suasana yang sedikit mendukung pemikiran teologis. Urusan perkawinan seluruhnya menjadi wewenang Gereja (dari segi hukum) dan dilepaskan dari konteks sosialnya (adat, kelompok). ${ }^{6}$ Meski demikian, mengenai saat awal sahnya perkawinan belum tercapai kesepakatan.

Ada yang menegaskan bahwa perkawinan mulai menjadi sah sejak suami-isteri menyatakan konsensus perkawinan (teori consensus). Kelompok lain menyatakan bahwa perkawinan menjadi sah setelah kemudian ada hubungan seksual suamiisteri (teori copula/consummatum). ${ }^{7} \mathrm{Me}$ nanggapi pandangan yang berkembang, Paus Alexander III mengajarkan bahwa perkawinan sudah sah sejak consensus, tetapi baru bersifat mutlak tak terceraikan setelah consummatio. Perkawinan orangorang Kristen baru sepenuhnya bersifat tak terceraikan apabila sudah merupakan "matrimonium ratum et consummatum". 
Mengenai makna perkawinan, pada masa ini masih simpang siur disebabkan oleh adat setempat yang berbeda-beda. ${ }^{8}$ Gereja (sebagaimana pendapat para teolog) memberi penegasan bahwa perkawinan melambangkan hubungan Kristus dan Gereja serta bersifat monogam dan tak terceraikan. ${ }^{9}$ Pada Konsili Verona untuk pertama kalinya perkawinan orang-orang Katolik disebut sebagai sakramen. ${ }^{10}$ Hal lain yang muncul adalah soal tujuan perkawinan. Muncul istilah fines primarii (tujuan-tujuan primer) dan fines secundarii (tujuan-tujuan sekunder). Keturunan, menghindari percabulan, persatuan jiwa dengan Allah dan melambangkan inkarnasi dikatakan sebagai tujuan primer perkawinan, sedangkan keluhuran (nobilitas) dan keindahan (pulchritudo) adalah tujuan sekunder. ${ }^{11}$

Pada masa skolastik (abad XIII -XV) ada perjumpaan teologi dengan teolog-filsuf dari kawasan Timur Tengah, seperti Averroes dan Avicenna (dua filsuf-teolog muslim), Avicebrol dan Maimonides (dua teologfilsuf Yahudi). ${ }^{12}$ Thomas Aquinas dan Bonaventura adalah tokoh pada masa ini. Mengenai perkawinan, para tokoh skolastik masih mengangkat tradisi sebelumnya, baik patristik maupun teologi abad XI-XII. ${ }^{13}$ Konsili Lyon (1274) menyebut sakramen perkawinan sebagai satu dari ketujuh sakramen Perjanjian Baru, karena membuahkan rahmat. Dan pada Konsili Florens (1439) ditegaskan bahwa perkawinan orang-orang kristen benar-benar sakramen (DS 1310-1312). ${ }^{14}$

Pada abad XVI (masa Reformasi) para reformator menolak ajaran Gereja Katolik bahwa perkawinan adalah sakramen. Mereka melihat perkawinan hanya sebagai lembaga kodrati yang luhur melebihi hidup selibat. ${ }^{15}$ Perkawinan adalah suatu gaya hidup sipil di mana unsur ilahi jelas ada, tetapi unsur ilahi ini tidak lantas menjadikannya sakramen (seperti Baptisan, Perjamuan Kudus). Dasar para reformator adalah teks Mat 5:32; dan 19;19 di mana ada pengecualian untuk memutuskan perkawinan. Oleh karenanya Gereja Reformasi kadang-kadang memberikan izin perceraian dan pernikahan yang kedua.
Menanggapi pandangan perintis Gereja Reformasi, Gereja Katolik dalam Konsili Trente (1545-1563) dengan tegas menyatakan bahwa perkawinan orang-orang Kristen benar-benar merupakan sakramen.

Pada tahun 1880 Paus Leo XIII mengeluarkan ensiklik tentang perkawinan Kristiani, Arcanum Divinae Sapientiae. Paus menyodorkan kembali gagasan teologi skolastik dalam teropong Konsili Trente yang mempertahankan kompetensi dan kuasa Gereja Katolik atas perkawinan orang yang telah dibaptis (no. 1-15).

Pada tanggal 27 Mei 1917 Tahta Suci (Paus Benedictus XV yang menggantikan Paus Pius X) mengesahkan Kitab Hukum Gereja $^{16}$ yang mulai diberlakukan pada 19 Mei 1918. Kodeks ini juga mengatur perkawinan, yang dilihat sebagai kesatuan tetap seorang pria dan seorang wanita yang diangkat menjadi sakramen oleh Yesus Kristus, yang diteguhkan dengan persetujuan kedua pihak secara sah (Kanon 1012 $\S 1$ dan 2); Tentang tujuan perkawinan dari sifat kodratinya terarah kepada kesejahteraan suami-isteri serta kelahiran dan pendidikan anak (Kanon 1013 \$1).

Tahun 1968 Paus Paulus VI menegaskan peran Allah dalam perkawinan (Ensiklik "Humanae Vitae" no.8). Suamiisteri memberikan diri timbal balik dengan cinta yang total menuju kepada persatuan yang eksklusif dan bekerjasama dengan Allah untuk kelahiran baru (Humanae Vitae, no.9).

Paus sesudahnya, Paus Yohanes Paulus II nampaknya juga memberikan perhatian serius terhadap perkawinan. Seruan Apostoliknya, "Familiaris Consortio" (22 November 1981), menegaskan kembali sakramentalitas perkawinan Katolik dan juga disiplin Gereja sebelumnya. Cinta kasih suami-isteri berciri menyatukan jiwabadan, bersifat tak terceraikan dan kesetiaan dalam penyerahan diri timbalbalik yang definitif, dan terbuka pada keturunan (Familiaris Consortio, no.13). Keturunan dan pendidikan anak menjadi mahkota dari lembaga perkawinan dan cinta kasih suami-isteri. 


\section{Perkawinan menurut Kitab Hukum Kanonik}

Kitab Hukum Kanonik mengatur tentang perkawinan dalam Kanon 10551165. ${ }^{17}$ Kanon ini merumuskan dengan bahasa normatif ajaran mengenai perkawinan, khususnya yang terumus dalam "Gaudium et Spes" no. 48. Kanon 1055 § 1 menjelaskan secara doktrinal pengertian dari perkawinan dalam Gereja Katolik. Unsur-unsur esensial dan kodrati dari perkawinan menunjuk kepada persekutuan seluruh hidup yang terarah kepada kesejahteraan suami-isteri, kelahiran dan pendidikan anak. Perkawinan antara dua orang yang dibaptis diangkat oleh Kristus ke martabat sakramen. Perkawinan merupakan sebuah perjanjian (foedus, covenant) antara pria dan wanita untuk membentuk kebersamaan seluruh hidup.

Kesepakatan dilihat sebagai causa efficiens dari suatu perkawinan (Kanon $1057 \S 1)$. Kesepakatan ini dilakukan oleh dua orang pribadi yang berbeda seksualitas (lihat Kanon $1057 \S 2$ ). Oleh karenanya perkawinan merupakan consensus consensualis dan bukan consensus realis. Sejauh sudah terjadi kesepakatan bersama, perkawinan sudah terjadi meskipun belum disempurnakan dengan hubungan seksual. ${ }^{18}$ Objek kesepakatan tersebut adalah hak eksklusif dan tetap atas tubuh pasangannya dengan tujuannya yang utama yaitu keturunan. ${ }^{19}$ Namun hak atas tubuh ini harus tetap dipahami sebagai salah satu aspek dari kesepakatan perkawinan. Objek kesepakatan perkawinan tidak terbatas kepada hak atas tubuh melainkan kebersamaan seluruh hidup yang arahnya adalah kesejahteraan suami-isteri, kelahiran dan pendidikan anak.

\section{KONTRASEPSI DALAM PENILAIAN MORAL GEREJA KATOLIK}

\section{Kontrasepsi dalam Kitab Suci}

Perkembangan pemahaman Kristiani mengenai etika seksual kiranya mendapat struktur dasarnya dalam Kitab Perjanjian Lama di mana dalam ikatan perkawinan laki-laki dan perempuan dihubungkan secara seksual. ${ }^{20}$ Terkait dengan kontra- sepsi, dasar utama adalah teks Kej 38:8-9 tentang Onan yang diminta oleh Yehuda untuk menikahi Tamar (janda kakaknya, Er) untuk memberikan keturunan bagi kakaknya yang meninggal tanpa meninggalkan seorang anak. Onan tidak mengikuti perintah ayahnya dan membuang air maninya sendiri (coitus interruptus) ketika berhubungan seks dengan Tamar. Tindakan Onan itu dinilai jahat di mata Tuhan. Tindakan Onan itu dinilai sebagai "kontrasepsi' dan dipandang buruk oleh pencerita. $^{21}$

Dalam Perjanjian Baru tidak ada teks yang secara khusus membahas kontrasepsi, tetapi mengenai perkawinan. Pada dasarnya Injil mengajarkan bahwa perkawinan adalah baik adanya. Yesus menegaskan kembali ajaran yang ada dalam Kejadian 1 dan 2 dalam terang ilahi (Mrk 10:7-8; Mat 19:4-6; Yoh 2:1-12). Lukas juga menunjukkan sikap Yesus yang mengutuk perkawinan kedua sesudah perceraian (Luk 16:18). Teks-teks tentang perkawinan dalam Perjanjian Baru membawa pesan spesifik bagi suami dan isteri (Ef 5:25-33).

Teks-teks khusus Perjanjian Baru (Mrk 10:7-8; Mat 19:4-6; Luk 16:18; Ef 5:25-33; 1 Tim 5:14; 1Kor 7-10; Rm 1:24-27; 5:12.20) tentang keperawanan, perkawinan, hubungan seksual, dosa menyediakan dasar-dasar dari mana doktrin Katolik tentang kontrasepsi dikembangkan.

\section{Pandangan tentang Kontrasepsi pada Awal Kekristenan}

Tulisan-tulisan kaum Stoa dalam memahami alam dan keberadaan manusia dan problematikanya memiliki pengaruh pada pandangan Kristiani, terlebih pada ajaran para Bapa Gereja. Filsafat Stoa $^{22}$ berkembang dipelopori oleh Zeno (366-264 SM) di Athena. Pandangan Stoa tentang alam sangat kuat. Manusia harus hidup menyesuaikan diri dengan alam (Diogenes 7.87). Kaum Stoa berusaha mengendalikan keinginan tubuh agar mereka mandiri, tidak tergantung pada kekuatan dari luar. Mereka mencurigai peran negatif nafsu dalam perkawinan. Pandangan Stoa ini ikut membentuk gagasan para Bapa Gereja tentang perkawinan. ${ }^{23}$ 
Bagi Kekristenan, Tradisi Yahudi tidak hanya mewariskan Kitab Suci melainkan juga Talmud ${ }^{24}$, Tosefta dan Midrash. ${ }^{25}$ Dalam Talmud Babilonia, Niddah 13a ditegaskan adanya hukuman keras untuk masturbasi. Seorang rabbi Palestina, Johanan ben Naphaha mengatakan: "Siapapun yang memancarkan air mani sia-sia setimpal dengan hukuman mati. "Yebamoth 13b menyebutkan, para rabbi mengajarkan bahwa tindakan Onan adalah tidak natural. Hanya dalam kasus khusus, seperti adanya bahaya bagi kesehatan si wanita ketika ia sedang menyusui atau hamil, kontrasepsi diijinkan (Niddah $45 a) .{ }^{26}$

Klemens dari Alexandria (153-217M) mengajarkan bahwa hubungan seksual menemukan ukurannya dalam perkawinan. Dalam perkawinan prokreasi adalah karya yang baik sebagai bentuk kerjasama dengan karya Sang Pencipta (Clement, Pedagogus 2.10.95.3). Pandangan Klemens ini dipengaruhi oleh Musonius Rufus yang menyatakan bahwa satu-satunya tujuan yang sah dalam perkawinan adalah untuk prokreasi. ${ }^{27}$ Pandangan tersebut menjadi pemahaman yang dominan para Bapa Gereja dan para teolog abad pertengahan.

Agustinus dari Hippo (430 M) yang menanggapi gagasan Manikheisme menulis dua buku: The Morals of the Manichaeans (De moribus Manichaeorum) dan The Morals of the Catholic Church (De moribus ecclesiae catholicae). ${ }^{28}$ Gereja Katolik mengajarkan, kata Agustinus, perkawinan itu baik dan prokreasi adalah tujuan utama dalam hubungan seksual perkawinan. Agustinus menegaskan bahwa alasan hubungan seksual dalam perkawinan bukan untuk kesenangan melainkan untuk meneruskan keturunan (Agustinus, Reply to Faustus the Manichaean, XXII, 30). Agustinus menyebut mereka yang "meskipun disebut sebagai suami dan isteri" menolak dan bahkan menelantarkan anak-anak yang lahir bagi mereka melawan kehendak mereka (On Marriage and Conscupiscence/De Nuptiis et Concupiscentia, I.15.17).

\section{Kontrasepsi dalam Gereja Katolik Modern}

\section{Ensiklik "Casti Connubii"(31 Desember 1930)}

Ensiklik yang dikeluarkan oleh Paus Pius XI ini tidak bicara soal kontrasepsi secara khusus tetapi tentang perkawinan kristiani pada umumnya. ${ }^{29}$ Paus menyinggung soal kejahatan yang berkaitan dengan hubungan seks sebagai perendahan martabat perkawinan melalui drama, novel, film, dan bahkan karya-karya ilmiah yang melanda lapisan masyarakat dan menumbuhkan sikap pemuasan nafsu yang tak terkendali (no. 45-46).

Paus menegaskan hubungan suamiisteri (hubungan seksual) ditakdirkan secara alamiah menghasilkan keturunan/ anak. Mereka yang sengaja menggagalkan kekuatan alamiah tersebut berdosa melawan kodrat. Tindakannya secara intrinsik adalah jahat (no.54). Hubungan seksual yang dilakukan sedemikian rupa sehingga perbuatan itu dengan sengaja menghalangi kekuatan alaminya untuk menghasilkan kehidupan adalah pelanggaran terhadap hukum Allah dan hukum kodrat, dan mereka yang menuruti kehendak tersebut dicap bersalah oleh karena dosa berat (no.56).

\section{Kontrasepsi menurut Konsili Vatikan II dalam Dokumen "Gaudium et Spes"}

Konsili Vatikan II tetap mempertahankan ajaran Tradisi sebelumnya mengenai kontrasepsi yang dihubungkan dengan perkawinan (no. 47-52). Dewasa ini martabat perkawinan dicemari oleh tindakantindakan manusia yang menodai kesucian perkawinan. Cinta perkawinan juga sering dicemarkan oleh cinta diri, gila kenikmatan dan ulah / cara yang tidak halal melawan timbulnya keturunan.

Hubungan seks suami-isteri adalah ungkapan istimewa dari cintakasih mereka, maka harus dipandang luhur dan terhormat serta dijalankan dengan cara manusiawi (no.49). Tindakan itu harus selalu terarahkan kepada keturunan dan kesatuan suami-isteri. Anak-anak adalah karunia perkawinan yang paling luhur, meskipun hal itu tidak mengesampingkan 
tujuan-tujuan luhur yang lain. Menyalurkan hidup dan mendidik anak merupakan perutusan khas suami-isteri sebagai mitra kerja Allah Pencipta dan bagaikan penerjemah-Nya (no.50).

Pemecahan masalah tentang pertambahan jumlah anak hendaknya tidak melawan ajaran Magisterium Gereja, apalagi dengan melakukan pembunuhan. Kehidupan sejak saat pembuahan harus dilindungi dengan sangat cermat (no.51). Moralitas tindakan manusia tidak hanya tergantung dari maksud atau alasanalasannya saja.

\section{Ensiklik "Humanae Vitae"}

Ensiklik yang dikeluarkan oleh Paus Paulus VI pada 25 Juli 1968 ini secara khusus berbicara soal pengaturan kelahiran. Ensiklik ini menuai banyak kritik. Pada tahun 1990-an mayoritas umat katolik tidak setuju dan berbeda pendapat mengenai kontrasepsi dan menilai "Humanae Vitae" tidak konsisten dengan perkembangan ajaran Gereja tentang seksualitas dan pentingnya pembatasan keluarga yang bertanggung jawab di dunia modern. ${ }^{30}$

Ensiklik "Humanae Vitae" mengajarkan dengan jelas bahwa setiap dan semua "tindakan perkawinan" harus terbuka untuk kehidupan baru. ${ }^{31}$ Tugas suami-isteri yang paling serius adalah menjadi rekan kerja yang bebas dan bertanggung jawab bagi Allah Pencipta (no. 1). Berkaitan dengan persoalan-persoalan kependudukan (terlebih soal moral) Otoritas Gereja mempunyai kewenangan untuk menafsirkannya. Demi menciptakan keharmonisan dalam rumah tangga suami-isteri tidak boleh melakukan hal-hal yang melawan hukum alam maupun hukum Allah meskipun harus berkorban luar biasa (no. 2-4).

Perkawinan diadakan oleh Sang Pencipta untuk mewujudkan dalam diri manusia desain kasih-Nya sendiri (no. 8), meskipun secara alamiah tidak semua hubungan seksual selalu diikuti dengan kelahiran baru, tetapi setiap hubungan seksual suami-isteri harus selalu terbuka pada kelahiran baru (no. 11). Ajaran itu didasari oleh makna unitif dan makna prokreatif hubungan suami-isteri (no. 12). Segala usaha untuk menghilangkan salah satu atau kedua makna hubungan suamiisteri itu melawan hukum alam dan hukum Allah, termasuk di dalamnya sterilisasi, entah sementara atau selamanya (no. 14). Tidaklah dapat dibenarkan secara moral, bahkan dengan alasan yang berat, untuk melakukan tindakan yang jahat meskipun tujuannya adalah baik.

Jika harus melakukan pengaturan kelahiran, oleh karena alasan fisik dan psikologis atau oleh karena alasan yang lain, suami-isteri boleh mengatur kelahiran dengan memperhatikan siklus alamiah, karena dengan menggunakan metode masa tidak subur ini mereka tidak melawan prinsip moral yang sudah ditekankan sejak awal (no. 16). Dengan menolak metode buatan, Gereja membela martabat hubungan suami-isteri (no. 18).

\section{Anjuran Apostolik "Familiaris Consortio" (22 November 1981)}

Anjuran Apostolik ini dikeluarkan oleh Paus Yohanes Paulus II. Berkaitan dengan tema kontrasepsi, Paus Yohanes Paulus II masih meneruskan ajaran para pendahulunya, dengan secara khusus merujuk kembali ajaran Paus Paulus VI dalam ensiklik "Humanae Vitae". Paus menegaskan bahwa situasi zaman sekarang lebih membutuhkan kebijaksanaan dari pada masa yang silam (no.8). Kebudayaan modern perlu diarahkan agar sesuai dengan kebijaksanaan ilahi.

Paus menyebut bahwa lembaga perkawinan sendiri dan cintakasih suamiisteri, menurut rencana Allah tertujukan kepada timbulnya keturunan dan pendidikan anak-anak yang merupakan mahkota mereka. ${ }^{32}$ Meski demikian, bagi mereka yang tidak memiliki keturunan, kehidupan suami-isteri tidaklah kehilangan nilainya.

Dalam mengatasi persoalan populasi Gereja memanggil semua orang untuk membela kehidupan, lebih-lebih mereka yang adalah pasangan suami-isteri. Gereja mengecam dan menolak dengan tegas segala pelanggaran berat terhadap martabat manusiawi dan keadilan dan segala 
kegiatan pemerintah atau para penguasa lain untuk mengembangkan kontrasepsi atau lebih buruk lagi - sterilisasi dan pengguguran yang disengaja (no.30).

Menggunakan kontrasepsi mengingkari makna prokreatif hubungan suami-isteri dan dengannya manusia bertindak sebagai "penilai' terhadap rencana ilahi, memanipulasi dan memerosotkan seksualitas manusiawi (no.32). Tindakan ini tidak hanya merupakan penolakan untuk terbuka bagi kehidupan, melainkan juga pemalsuan kebenaran inti cintakasih suami-isteri, yang terarah kepada penyerahan diri seutuhnya. Paus menyarankan untuk memanfaatkan masa-masa ketidaksuburan pada perempuan untuk mengatur kelahiran karena tetap menghormati hubungan tak terceraikan antara makna unitif dan makna prokreatif pada seksualitas manusiawi dan bertindak sebagai "pelayan" rencana Allah (no.32).

\section{Ensiklik "Evangelium Vitae" (25 maret 1995)}

Ensiklik Paus Yohanes Paulus II ini berbicara khusus mengenai nilai (yang tak dapat diganggu gugat) hidup manusia. Ensiklik ini dikeluarkan berdasarkan fenomen adanya ancaman yang luar biasa terhadap hidup individu dan masyarakat (no.3). Persoalan kontrasepsi disebut oleh Paus dalam konteks penjelasannya mengenai aborsi. Ada anggapan bahwa kontrasepsi menjadi solusi yang paling efektif untuk melawan aborsi. Kelompok pro-aborsi menganggap bahwa dengan memberikan ajaran moralnya mengenai pengaturan kelahiran yang melarang alatalat kontrasepsi, Gereja Katolik mempromosikan aborsi. Budaya pro-aborsi yang sangat kuat berlawanan dengan ajaran Gereja mengenai kontrasepsi (no.13).

Kontrasepsi dan aborsi memang memiliki nilai kejahatan yang berbeda. Kontrasepsi bertentangan dengan nilai prokreatif tindakan seksual suami-isteri, sedangkan aborsi menghancurkan kehidupan manusia. Paus menyadari bahwa kadangkala kontrasepsi dan aborsi dipraktikkan oleh karena adanya tekanan/kesulitan hidup. Kehidupan baru, hasil dari hubungan seksual, menjadi musuh yang harus dihindari, dan aborsi menjadi respon yang paling mungkin ketika kontrasepsi gagal (no.13). Kontrasepsi, sterilisasi dan aborsi bukan solusi yang benar untuk mengendalikan pertambahan penduduk (no.91) dan jangan dipakai karena alasan "demografi” (no.16).

\section{PRAKTIK PENGATURAN KELAHIRAN DI PAROKI ST. YUSUF PEKERJA GONDANGWINANGUN KLATEN}

Paroki St. Yusuf Gondangwinangun mengenalkan metode pengaturan kelahiran dan ajaran Gereja mengenai hal tersebut kepada calon pasutri melalui Katekese Persiapan Perkawinan. Hal itu dimaksudkan supaya calon pasutri bisa bertindak secara bijaksana dalam praktik pengaturan kelahiran dalam keluarga yang akan mereka bangun.

\section{Hasil Penelitian}

Sebagian besar responden (81.7\%) menggunakan alat kontrasepsi dalam mengatur kelahiran. Yang menggunakan kontrasepsi jenis Intra Uterine Device (IUD) sebesar 35\%, jenis Hormon (pil, suntik, susuk/implan) sebesar $13.3 \%$, jenis barrier/ penghalang (kondom, diaphragma, spermicide, cervical cap), dan sterilisasi tetap (vasektomi dan tubektomi) sebesar $8.3 \%$, dan sebesar $18.3 \%$ menggunakan metode alamiah.

Dari jumlah itu, sebesar 50\% responden dengan pendidikan SD menggunakan kontrasepsi jenis IUD, 25\% menggunakan kontrasepsi jenis penghalang, dan 25\% lainnya menggunakan metode pengaturan secara alamiah. Responden dengan pendidikan SLTP, $42.8 \%$ menggunakan kontrasepsi jenis IUD, 14.2\% menggunakan jenis hormon, sedangkan $28.6 \%$ menggunakan metode sterilisasi tetap dan $14.3 \%$ menggunakan metode alamiah.

Responden dengan pendidikan SLTA/ SMK, $41.4 \%$ menggunakan kontrasepsi jenis IUD, $17.2 \%$ menggunakan jenis hormon, 20.7\% menggunakan kontrasepsi jenis barrier, $10.3 \%$ menggunakan metode sterilisasi tetap dan $10.4 \%$ menggunakan metode alamiah. Responden dengan 
pendidikan diploma - sarjana, $22.2 \%$ menggunakan kontrasepsi jenis IUD, $11.1 \%$ menggunakan jenis hormon, dan 38.9\% kontrasepsi jenis barrier, sedangkan 27.8\% menggunakan secara alamiah. Responden dengan pendidikan pascasarjana 100\% menggunakan metode alamiah. Responden yang tidak sekolah 100\% menggunakan kontrasepsi jenis penghalang.

\section{Pengaruh Pengetahuan Responden terhadap Praktik Pengaturan Kelahiran}

Secara umum $70 \%$ responden memahami kontrasepsi sebagai usaha manusia untuk mencegah terjadinya kehamilan dan $30 \%$ lainnya memahami sebagai alat KB. Cukup besar responden yang tidak mengetahui risiko (46.7\%) maupun sifatsifat abortif (60\%) dari alat kontrasepsi yang mereka gunakan. Lebih dari separuh responden yang menggunakan alat-alat kontrasepsi yang bersifat abortif (55.2\%) mengatakan bahwa mereka tidak tahu tentang sifat alat-alat tersebut. Menurut mereka alat-alat kontrasepsi adalah cara yang aman (22.5\%), efektif (14.3\%), dan praktis (2\%) untuk mengatur kelahiran. Mengapa tidak menggunakan metode alamiah? Mayoritas responden (42.9\%) tidak memberikan jawaban, sedangkan 26.5\% mengatakan takut lupa dan takut mengalami kegagalan. Lainnya, 22.4\% mengatakan bahwa metode pengaturan secara alamiah sulit dipraktikkan dan tidak begitu yakin dengan tingkat keberhasilannya. Sisanya mengatakan tidak ada waktu dan kurang sabar (4.1\%) serta menstruasi isteri yang tidak teratur (4.1\%).

Alasan lain yang dimunculkan oleh mereka yang menggunakan kontrasepsi adalah demi cinta kepada pasangannya. Menurut mereka keutuhan keluarga (suami-isteri) lebih utama dibandingkan dengan ajaran Gereja (dalam hal ini adalah mengenai pengaturan kelahiran). Situasi menuntut mereka melakukannya. Mereka tidak pernah tahu kapan keinginan (hubungan seksual) itu muncul. Dan pada saat keinginan itu datang, mereka tidak yakin dalam situasi subur atau tidak subur maka pilihan pertama adalah menggunakan alat kontrasepsi.
Berkaitan tentang ajaran Gereja, lebih dari separuh responden (55\%) mengira bahwa Gereja mengijinkan penggunaan alat-alat kontrasepsi dan hanya sekitar 1.7\% yang mengatakan tidak tahu. Hal ini menimbukan pertanyaan, apakah Gereja kurang jelas menyampaikan kepada mereka (umat) mengenai ajaran Gereja ini? Ataukah jawaban ini muncul untuk membenarkan praktik yang dilakukan?

Rupanya mayoritas responden tahu ajaran Gereja hanya melalui KPP (61.7\%), sebagian lain (15\%) belajar secara mandiri, dan $1.7 \%$ memperolehnya dari para imam. Sisanya, $21.6 \%$ belajar dari sumber-sumber lain. Dari data ini sepertinya kita perlu melihat efektivitas KPP untuk menyampaikan ajaran-ajaran Gereja ini. Mungkin praktik pengaturan kelahiran dengan kontrasepsi yang cukup besar dikarenakan faktor ketidaktahuan.

Lebih lanjut saat ditanyakan kepada mereka tentang alasan Gereja melarang praktik kontrasepsi tidak semua responden memberikan jawaban. Dari jawaban yang terkumpul, 61.5\% mengatakan bahwa kontrasepsi melawan kehidupan dan merupakan suatu bentuk pembunuhan terhadap embrio. Responden lainnya (23.1\%) mengatakan bahwa kontrasepsi mengandung banyak risiko dan tidak baik bagi kesehatan mereka. Sisanya (15.4\%) menjawab bahwa kontrasepsi melawan hukum alam dan hukum kodrat. Dari jawaban mereka ini sebetulnya umat memiliki pemahaman yang cukup baik terhadap alasan-alasan Gereja melarang kontrasepsi. Namun pemahaman ini tidak disertai dengan tindakan konkret, karena dari mereka yang menjawab ternyata hanya ada $19.2 \%$ responden yang tidak mempraktikkan kontrasepsi, sisanya tetap mempraktikkan kontrasepsi.

Terhadap responden yang menggunakan metode alamiah - meskipun secara prosentase cukup kecil (18.3\%) - terungkap bahwa mereka memilih metode ini karena menurut mereka metode ini lebih murah, aman dan manusiawi (81.8\%) juga efisien (9.1\%). Sebagian lagi (9.1\%) mengatakan kontrasepsi adalah pilihan lain/alternatif jika metode alamiah tidak bisa dijalankan. 
Di sisi lain mereka mengatakan dengan metode ini mereka mendapat pengayaan dalam nilai-nilai lainnya bukan semata pengaturan kelahiran. Nilai yang paling menonjol muncul adalah nilai kesabaran dan pengendalian diri.

Secara umum, berdasar data tersebut mungkin kita bisa mengatakan bahwa faktor pengetahuan yang dimiliki oleh responden tidak begitu mendapatkan perannya ketika berhadapan dengan situasi konkret dalam praktik pengaturan kelahiran.

Prosentase yang cukup besar dalam praktik kontrasepsi ini, selain didasari oleh gagasan tentang faktor situasi, juga karena mereka yakin bahwa alat-alat kontrasepsi memiliki tingkat keberhasilan yang cukup besar untuk mencegah kehamilan. 85.7\% responden yang menggunakan kontrasepsi mengatakan tidak pernah gagal dan hanya 14.3\% pernah gagal. Dan bisa jadi karena memiliki tingkat keberhasilan yang tinggi ini, sebesar $91.7 \%$ dari semua responden menyetujui praktik pengaturan kelahiran dengan kontrasepsi.

\section{Penilaian Moral atas Praktik Pengaturan Kelahiran dengan Kontrasepsi}

Apakah penilaian moral terhadap praktik kontrasepsi adalah buruk begitu saja karena tidak sesuai dengan ajaran Gereja? Praktik pengaturan kelahiran dengan kontrasepsi dapat dinilai secara moral sejauh orang sadar, tahu dan sengaja memilihnya. Jika pasutri pada akhirnya tidak melakukan hubungan seksual oleh karena mereka takut melanggar ajaran Gereja dan takut berdosa, mereka jatuh pada etika peraturan yang bagi Immanuel Kant (1724-1804) adalah suatu heteronomy moral. ${ }^{33}$ Moralitas manusia tidak lebih daripada mengetahui peraturan-peraturan moral itu dan hidup sesuai dengannya.

Dalam penelitian (khususnya dalam wawancara lebih lanjut kepada pasutri) ternyata mereka lebih memilih untuk melakukan hubungan seksual dengan alasan cinta meski harus menggunakan kontrasepsi. Manusia bisa saja keliru, tetapi tidak berarti bahwa keputusan yang ternyata salah, secara moral juga salah. Magnis Suseno menyebut bahwa keputusan yang ternyata salah atau keliru tetapi secara moral tidak bersalah, atau dalam bahasa agama tidak berdosa ketika pengambilan keputusan itu dia yakin bahwa itulah yang wajib dilakukannya. ${ }^{34}$ Jika keputusan untuk menggunakan kontrasepsi demi keutuhan cinta dan kebahagiaan hidup bekeluarga yang bagi mereka wajib dilakukan maka tindakan tersebut dari sudut pandang ini secara moral adalah benar.

Dalam moralitas Kristiani dirumuskan bagaimana orang Kristiani senantiasa terus menerus memperbarui diri dalam Kristus. ${ }^{35}$ Moralitas kristiani berdasarkan pada Kristus, Allah yang menjelma dan datang ke dunia. Panggilan dalam Kristus bukan sekedar menjadi anugerah dan rahmat tetapi pada waktu yang bersamaan menjadi perintah untuk hidup sebagai manusia yang ditebus.

Jika praktik pengaturan kelahiran dengan kontrasepsi mau dihubungkan dengan hidup beriman, kita bisa merujuk kepada dasar moralitas kristiani tersebut. Sebagaimana Allah mencintai manusia dengan sedemikian besar sehingga mengurbankan anak-Nya yang tunggal untuk penebusan dosa manusia. ${ }^{36}$ Panggilan kristiani ini menembus pikiran dan tindakan manusia untuk mencintai sesamanya seperti diteladankan oleh Kristus.

Oleh karena itu, pasutri memilih menggunakan atau tidak menggunakan kontrasepsi seharusnya bukan karena adanya ajaran moral Gereja mengenai hal itu, tetapi karena kesadaran dari dirinya sendiri bahwa pilihannya itu adalah sesuatu yang bernilai dan sebagai tanggung jawabnya. Sesuatu yang bernilai ini tentu harus selalu dihubungkan dengan hidupnya sebagai manusia yang mencari dan menuju kepada Allah dalam hidup dan keberadaannya.

\section{PENUTUP}

\section{Pemahaman mengenai Pengaturan Kelahiran}

Sebagai suatu sarana atau metode untuk mengatur kelahiran, alat-alat kontrasepsi dipilih oleh sebagian besar pasutri karena mudah, praktis dan murah. Pilihan itu ternyata kadangkala tidak disertai 
dengan pemahaman yang cukup terhadap alat-alat tersebut. Pertimbangan baik dan buruknya (secara moral Katolik) metode tersebut kurang mendapatkan perhatian.

Persoalan pengaturan kelahiran memang bukan persoalan yang mudah untuk dipecahkan. Di satu sisi pasangan suamiisteri tidak menginginkan jumlah kelahiran yang besar dalam keluarganya dan mempertahankan keutuhan cinta terhadap pasangan, di sisi lainnya mereka terbentur pada ajaran moral Gereja.

Alat kontrasepsi pada masa ini sangatlah mudah diperoleh karena didukung oleh pemerintah. Namun pengawasan terhadapnya agak lemah. Alat-alat ini sering disalahgunakan pihak-pihak yang tidak berkepentingan sehingga menimbulkan persoalan moral yang baru.

\section{Pemahaman Mengenai Ajaran Gereja}

Pengetahuan dan pemahaman seseorang atas ajaran Gereja memang tidak memberi jaminan bahwa orang akan melakukan seperti apa yang diketahui atau dipahaminya. Hal ini bisa dilihat dari data yang berhasil dikumpulkan dalam penelitian. Meskipun demikian hal itu bukan berarti bahwa kita tidak perlu mengajarkan ajaran Gereja tersebut.

Pengetahuan dan pemahaman yang setengah-setengah tentang ajaran Gereja bisa menjadi alasan seseorang untuk tidak bertindak sesuai dengan ajaran itu. Data penelitian menunjukkan bahwa tingkat ketidaktahuan umat terhadap ajaran Gereja mengenai pengaturan kelahiran cukup besar. Mungkinkah hal ini menunjukkan kurangnya perhatian para pastor atas persoalan mengenai moralitas pengaturan kelahiran? Jika umat tidak tahu dan tidak memahami ajaran moral Gereja, khususnya mengenai pengaturan kelahiran, bagaimana Gereja menuntut mereka untuk menjalankan ajaran itu?

Menyampaikan ajaran Gereja mengenai pengaturan kelahiran merupakan wujud tanggung jawab para pastor untuk menjaga nilai-nilai luhur yang terkandung dalam perkawinan katolik. Jika umat lebih paham mengenai ajaran moral Gereja menyangkut soal praktik pengaturan kelahiran, kiranya mereka akan terbantu dalam mewujudkan ajaran itu dalam praksisnya.

\section{Relevansi dan Refleksi atas Ajaran Moral Gereja mengenai Pengaturan Kelahiran}

Ada dua hal yang mendasar yang harus diperhatikan oleh otoritas Gereja mengenai ajaran moralnya ini. Pertama, pembuat ajaran moral tersebut (pemimpin/otoritas Gereja) tidak mengalami situasi konkret sebagaimana dialami oleh pasangan suamiisteri. Sebagian besar (bahkan bisa dikatakan semua) pembuat ajaran moral adalah para imam dan kaum religius. Mereka tidak menghayati hidup perkawinan.

Hubungan seksual merupakan kekhasan hidup perkawinan yang tidak dijalani oleh para imam dan kaum religius. Segala macam situasi yang berkaitan dengan hubungan seksual (bukan hanya dorongan) tidak dialami oleh kaum religius. Tidak mungkin kita menuntut mereka yang menikah untuk beraskese (untuk tidak berhubungan seksual) sebagaimana para imam dan kaum religius. Mereka tidak berada pada situasi seperti yang dihadapi oleh para imam dan kaum religius. Bukankah, kesejahteraan suami-isteri (bonum coniugum) merupakan ciri kodrati perkawinan sebagaimana dirumuskan oleh Kitab Hukum Kanonik (kan.1055§1)? Maka, dalam merumuskan ajaran moral yang menyangkut kehidupan pasangan yang menikah sebaiknya melibatkan juga mereka yang menikah.

Kedua, penilaian moral terhadap suatu tindakan konkret dapat mengalami perkembangan sesuai dengan zamannya ${ }^{37}$ kecuali dalam hal nilai-nilai moral yang berlaku umum seperti nilai kejujuran. Nilai ini dapat dipertahankan dan diterapkan di segala macam situasi peradaban manusia. Apakah rumusan ajaran moral tentang metode pengaturan kelahiran "harus" dipertahankan selama-lamanya? Hasil penelitian menunjukkan bahwa banyak responden tidan mampu menjalani ajaran Gereja Katolik tentang pengaturan.

Ajaran moral Gereja mengenai pengaturan kelahiran memang didasarkan pada nilai-nilai luhur perkawinan, martabat dan 
sakramentalitasnya, yang dismpulkan dari Kitab Suci, Tradisi dan Magisterium Gereja. Gereja merumuskan ajaran itu untuk membantu pasangan suami-isteri menghayati nilai-nilai luhur perkawinan dengan setia. Namun Gereja harus berpikir ulang mengenai ajarannya tentang metode pengaturan kelahiran.

Sampai saat ini Gereja selalu mengajarkan bahwa setiap berhubungan seksual suami-isteri harus selalu terbuka kepada keturunan. Apakah tidak sebaiknya rumusan ajaran diubah menjadi setiap perkawinan harus terbuka kepada keturunan? Secara alami dalam siklus reproduksi perempuan ada masa subur dan tidak subur. Jika demikian bukankah kita bisa mengatakan bahwa secara natural pun ada saat di mana hubungan seksual "tidak terbuka" kepada keturunan? Hal itu berarti bahwa Allah pun tidak menghendaki bahwa setiap hubungan seks menghasilkan keturunan.

Sebaiknya Gereja merumuskan kembali ajaran moralnya mengenai pengaturan kelahiran agar ajaran itu sungguh bisa menjadi pegangan dan bisa dijalankan oleh umat. Mengenai metode pengaturan kelahiran yang tidak mengindahkan martabat hidup manusia (karena sifat-sifatnya yang melawan hidup manusia) Gereja tentu saja harus tetap mempertahankannya, karena manusia tidak berhak atas hidupnya sendiri maupun orang lain. Hidup adalah milik Allah dan oleh karenanya hanya Allah yang berhak atas hidup manusia.

\section{Pastoral Mengenai Pengaturan Kelahiran}

Di lapangan terlihat adanya sikap permisif pada banyak pasangan suami-isteri Katolik (khususnya responden yang memahami ajaran moral Gereja). Mereka tetap mempraktikkan pengaturan kelahiran dengan menggunakan alat-alat kontrasepsi yang sifat-sifatnya melawan kehidupan meskipun mereka tahu dan paham akan hal itu. Fenomen ini harus mendapatkan perhatian yang serius dari para gembala Gereja. Gereja jangan membiarkan situasi tersebut terus berlanjut. Berikut adalah beberapa hal yang perlu mendapatkan perhatian serius:
1. Manakah program pastoral yang tepat dan efektif untuk mengenalkan ajaran Gereja kepada pasangan suami-isteri katolik selain Katekese Persiapan Perkawinan?

2. Tim Pastoral Keluarga Paroki dapat memberikan pendampingan macam apa kepada pasangan suami-isteri pasca perkawinan?

3. Bagaimana para pastor dapat memberikan pengetahuan dan penjelasan yang lebih intensif kepada pasangan suamiisteri pasca perkawinan mengenai pengaturan kelahiran secara alamiah?

Langkah-langkah pastoral di bawah ini kiranya dapat diambil untuk mendorong pasangan suami-isteri Katolik untuk menjalankan praktik pengaturan kelahiran sesuai dengan ajaran moral Gereja:

1. Menyampaikan dengan jelas ajaranajaran moral Gereja mengenai metode pengaturan kelahiran. Ajaran-ajaran itu dapat disampaikan melalui Katekese Persiapan Perkawinan maupun dalam katekese sesudah pernikahan.

2. Dalam Katekese Persiapan Perkawinan perlu diberikan materi yang lengkap dan narasumber yang kompeten mengenai praktik pengaturan kelahiran. Secara khusus perlu dijelaskan metode pengaturan kelahiran secara alamiah yang didukung oleh Gereja.

3. Menumbuhkan kesadaran dalam diri umat akan pentingnya pertimbangan moral dalam mengatur kelahiran. Dalam melakukan hubungan seksual, suami-isteri hendaknya tidak hanya mencari kesenangan dan pemuasan diri melainkan juga mengusahakan terjadinya kehendak Allah.

4. Memberikan pemahaman yang tepat mengenai tujuan utama pengaturan kelahiran dalam keluarga-keluarga kristiani. Perlu ditekankan bahwa tujuan utama pengaturan kelahiran bukanlah untuk menekan angka kelahiran melainkan mewujudkan keluarga-keluarga yang bertanggung jawab.

5. Bagi pasangan yang sudah terlanjur menggunakan metode pengaturan kelahiran dengan kontrasepsi (yang kontraseptif maupun kontravita), hendaknya 
Gereja memberikan pendampingan untuk memberikan ketenangan hati kepada mereka. Terutama bagi pasangan yang memang tidak mengetahui bahwa tindakan mereka tidak sesuai dengan ajaran Gereja. Tindakan yang didasari oleh ketidaktahuan dan bukan karena sengaja melanggar suatu aturan moral tidak bisa dinilai secara moral baik atau buruk.

6. Memberikan pemahaman kepada umat mengenai hubungan antara ajaran iman dan ajaran moral dalam Gereja. Ajaran moral Gereja bukan semata ajaran yang bersifat manusiawi tetapi juga memberikan tuntunan dan pegangan bagi hidup orang beriman dalam menghayati imannya. Dengan ajaran ini, umat beriman dibantu untuk mengarahkan hidupnya kepada Allah melalui cara hidup manusiawi dengan sesamanya.

\section{Yohanes Sudaryanto}

Alumnus Magister Teologi Universitas Sanata Dharma Yogyakarta

\section{CATATAN AKHIR}

1 Konferensi Waligereja Indonesia, 2011, Pedoman Pastoral Keluarga, Obor, Jakarta, 55-60.

2 Penulis memilih umat Paroki St. Yusuf Gondangwinangun, Klaten sebagai target penelitian dengan alasan: 1) Ada keragaman sosial-ekonomi-pendidikan diantara umat paroki yang bisa penulis gunakan dalam pengumpulan data. 2) Ada kemungkinan yang cukup besar dapat bertemu dengan para calon responden dari sudut pandang geografis.

3 C. Groenen OFM, 1993, Perkawinan Sakramental. Anthropologi dan Sejarah Teologi, Sistematik, Spiritualitas, Pastoral, Kanisius, Yogyakarta, 144.

4 Markion tampil di Roma sekitar tahun 140M tetapi kemudian terpaksa meninggalkan Roma. Dia menyusun suatu "Kitab Perjanjian Baru", satu "kanon" yang memuat Injil Lukas dan sepuluh surat Paulus. Dia menolak Perjanjian Lama dan Allah Pencipta sebagaimana tampil dalam Perjanjian Lama, yang menciptakan manusia seksual dan perkawinan. Markion berpendapat bahwa seksualitas merupakan sesuatu yang jahat dan perkawinan terlarang. C. Groenen OFM, Perkawinan Sakramental. Anthropologi dan Sejarah Teologi, Sistematik, Spiritualitas, Pastoral, 150-151.

5 Al. Purwa Hadiwardoyo MSF, 1988, Perkawinan dalam Tradisi Katolik, Kanisius, Yogyakarta, 35.

6 C. Groenen OFM, Perkawinan Sakramental. Anthropologi dan Sejarah Teologi, Sistematik, Spiritualitas, Pastoral, 194.

7 Pendukung teori consensus adalah kelompok Petrus Lombardus. Menurutnya, persetujuan (consensus) ialah kontrak (pactio) perkawinan (coniugalis), mewujudkan perkawinan, meskipun tidak didahului atau disusul dengan sanggama. Sedangkan pendukung teori copula/consummatum adalah kelompok Gratianus dan Anselmus. Menurut mereka perkawinan terwujud melalui suatu proses yang dimulai dengan persetujuan formal (matrimonium ratum) dan diselesaikan dengan sanggama (consummatum). C. Groenen OFM, Perkawinan Sakramental. Anthropologi dan Sejarah Teologi, Sistematik, Spiritualitas, Pastoral, 199.

8 C. Groenen OFM, Perkawinan Sakramental. Anthropologi dan Sejarah Teologi, Sistematik, Spiritualitas, Pastoral, 196.

9 Lih. Jean Yves Lacoste. Ed., 2005, Encyclopedia of Christian Theology. Vol.1, Routledge, New York. London, 986-201.

10 C. Groenen OFM, Perkawinan Sakramental. Anthropologi dan Sejarah Teologi, Sistematik, Spiritualitas, Pastoral, 201.

11 Tokohnya adalah Simon dari Tours. Beberapa tokoh tidak setuju dengan pandangan umum tersebut. Salah satunya adalah Hugo San Vittore. Dia melihat perkawinan sebagai sakramen ganda. Ada "sakramen lebih besar' (sacramentum maius) dan "sakramen besar" (sacramentum magnum). Sakramen yang lebih besar menunjuk kepada tujuan pertama perkawinan yaitu kesatuan suami-isteri dalam cinta kasih rohaniah, sehingga keduanya bertumbuh dalam cinta kasih Allah dan saling membantu. Sedangkan sakramen besar menunjuk tujuan kedua yaitu keturunan (termasuk pengaturan nafsu seksual). Lih. C. Groenen OFM, Perkawinan Sakramental. Anthropologi dan Sejarah Teologi, Sistematik, Spiritualitas, Pastoral, 205.

12 C. Groenen OFM, Perkawinan Sakramental. Anthropologi dan Sejarah Teologi, Sistematik, Spiritualitas, Pastoral, 214. 
13 Bonaventura meneruskan pandangan Agustinus tetapi terpengaruh oleh filsafat Aristoteles dan "teologi baru" zaman itu. Bonaventura juga mengambil alih definisi sakramen Hugo San Vittore bahwa sakramen adalah penyerupaan (similitudo); yang menghadirkan berkat dan setelah dikuduskan menyampaikan rahmat rohani. Bonaventura cukup realistis melihat bahwa seringkali orang menikah dengan tujuan yang lain, yang baik, yang kurang baik, bahkan yang buruk. Tetapi perkawinan tetap saja terjadi (IV Sent, 30, chap.III; 30,1.3). Nilai atau tujuan yang lain itu juga membenarkan perkawinan (IV Sent.52,3.1; 52,3.2), termasuk hubungan seksual. Hubungan seksual tidak hanya bersangkutan soal keturunan, tetapi juga dengan sakramentalitas perkawinan. Thomas Aquinas menggabungkan tradisi dengan filsafat Aristoteles. Thomas mengangkat kembali gagasan Hugo San Vittore mengenai sakramen perkawinan yang menguduskan. Sakramen, menurut Thomas, bukan hanya tanda hal yang suci tetapi sebab rahmat aktual yang berpancar dari penderitaan Kristus. Karena perkawinan adalah sakramen maka sakramen itu pun menyebabkan rahmat (Sum. Theol. II,II 100,2.6). Bagi Thomas perkawinan merupakan gejala manusiawi secara esksistensial maupun secara Kristen. Thomas membedakan tiga segi yang tidak terpisah: officium naturae, officium civilitatis, dan officium gratiae (bdk. Sum. Theol. III, Supl. 42,2). Officiumnaturae adalah menyangkut tugas (officium) penerusan umat manusia dan secara manusiawi (Sum. Theol. 41,1) juga menyangkut merawat dan mendidik anak sampai dapat mandiri. Officium civilitate berkaitan dengan tugas sosial. Hal ini mau menunjukkan hubungan antara perkawinan dengan adat setempat. Sedangkan officium gratiae berkaitan dengan sakramentalitas perkawinan, lambang ikatan definitif antara Kristus dan Gereja. Lih. C. Groenen OFM, Perkawinan Sakramental. Anthropo-logi dan Sejarah Teologi, Sistematik, Spiritualitas, Pastoral, 217-234.

14 Al. Purwa Hadiwardoyo MSF, Perkawinan dalam Tradisi Katolik, 48. C. Groenen OFM, Perkawinan Sakramental. Anthropologi dan Sejarah Teologi, Sistematik, Spiritualitas, Pastoral, 238.

15 Al. Purwa Hadiwardoyo MSF, Perkawinan dalam Tradisi Katolik, 49.

16 Kitab Hukum ini (dikenal dengan Codex Iuris Canonici) adalah kumpulan hukum universal, eksklusif dan otentik yang disusun melalui proses yang cukup panjang (selama dua belas tahun) oleh para ahli, para konsultor dan para Uskup dari seluruh Gereja. KWI, 2006, Kitab Hukum Kanonik 1983 edisi resmi Bahasa Indonesia, Grafika Mardi Yuana, Bogor, 21.

17 Banyak hal dibahas dalam kanon ini berkaitan perkawinan mulai dari awal perjanjian sampai pada persoalan pemutusan ikatan perkawinan. Tentu saja dalam tulisan ini tidak akan dibahas seluruh kanon yang mengatur perkawinan, tetapi akan mengambil beberapa kanon yang berkaitan dengan tema tulisan ini.

18 Robertus Rubiyatmoko, 2001, Hukum Perkawinan Kanonik, Diktat Kuliah. Fakultas Teologi Wedabhakti, Yogyakarta, 2001, 7.

19 Sebagaimana dimaksudkan dalam KHK 1917, Kan $1081 \S 2$ : "Consensus matrimonialis est actus voluntatis quo utraque pars tradit et acceptat, perpetuum et exclucioum, in ordine ad actus per se aptos ad prolis generationem". Robertus Rubiyatmoko. Hukum Perkawinan Kanonik, 10.

20 Dasar teks ada di Kitab Kejadian 2, yang menegaskan bahwa Allah menciptakan perempuan sebagai penolong yang sepadan bagi laki-laki (Kej 2:18, 22-24). Allah juga memerintahkan manusia untuk "beranakcucu dan bertambah banyak" setelah Dia memberkati mereka (Kej 1:26-28). Rumusan "beranak-cucu dan bertambah banyak" juga dimaksudkan bagi semua makhluk hidup (Kej 1:22). Berkembang biak atau beranakcucu adalah anugerah dari Allah (Im 7:1314; Kej 9:1). John T. Noonan, Jr., 1966, Contraception. A History of Its Treatment by the Catholic Theologians and Canonists, The Belknap Press of Harvard University Press, Cambridge, Massachusetts, 30-31.

21 Beberapa tindakan seksual dalam perkawinan pun dikritik oleh Hukum Taurat. Hubungan seksual dengan wanita yang sedang menstruasi dianggap sama dengan perzinahan (Yeh 18:6; Im 18:19; 20:18). Mereka yang melakukannya haruslah dilenyapkan dari antara orang-orang sebangsanya. Tindakan tersebut dianggap menodai kekudusan umat Allah (Im 20:8). Tindakan seksual yang dianggap sebagai penodaan terhadap kesucian perkawinan, ialah coitus interruptus, bestiality, homoseksualitas dan segala macam bentuk prostitusi (Im 18:22; 20;13; 20:15; Ul 23:18). John T. Noonan, Jr., Contraception. 
A History of Its Treatment by the Catholic Theologians and Canonists, 35.

22 Filsafat Stoa menitikberatkan faktor individu berhadapan dengan pandangan Platonis dan Aristotelian. Filsafat Stoa terbagi dalam tiga kelompok: 1) the Ancient Stoa, tokohnya antara lain adalah Zeno, Cleanthes (331-232 SM) dan Chrysippus (282-206 SM). 2) The Middle Stoa, beberapa tokohnya adalah Panaetius (185-109 SM) dan Poseidonius (135-50 SM). 3) The Later Stoa, tokohnya adalah L. Annaeus Seneca (4-65), Musonius Rufus, Epictetus (50-138). Thomas Carson, Joann Cerrito, eds., 2003, The New Catholic Encyclopedia. Second edition, vol.13, Gale, Washington D.C, 534.

23 Misalnya, ajaran Klemens dari Aleksandria tentang tujuan dari perkawinan dipengaruhi oleh karya Musonius. Orang harus melepaskan diri dari hubungan seksual yang tidak rasional yang tidak mengarah kepada prokreasi (the Stromata. Book II. Chpt.XIII, On Marriage). Pada abad II, ajaran Origenes tentang hubungan seksual jelas dipengaruhi oleh ajaran Seneca. Komentar Lactantius pada abad III dalam kuliah tentang prokreasi adalah gema dari ajaran Ocellus Lucanus. Dan pada abad IV sebagian besar pernyataan keras dari Hieronimus diambil dari Seneca. John T. Noonan, Jr., Contraception. A History of Its Treatment by the Catholic Theologians and Canonists, 47-48.

24 Talmud menunjuk pada kumpulan hukum yang berwenang dalam tradisi Yahudi yang merupakan catatan dari tradisi hukum lisan dari beberapa rabbi Yahudi. Ada dua bagian: 1) Mishnah (catatan sampai abad II Kekristenan dan komentarnya), 2) Gemarah, yang dibagi dalam 2 bagian: the Palestinian (catatan samapai abad IV Kekristenan), dan the Babylonian (catatan yang dimulai dari abad 6 Kekristenan). Thomas Carson, Joann Cerrito, eds., The New Catholic Encyclopedia. Second edition, vol.13, 742.

25 Midrash adalah literatur Yahudi yang merupakan diskusi homiletik teks-teks Kitab Suci dengan tujuan untuk diterapkan dalam situasi zaman itu.

${ }^{26}$ John T. Noonan, Jr., Contraception. A History of Its Treatment by the Catholic Theologians and Canonists, 50.

27 Thomas Carson, Joann Cerrito, eds., The New Catholic Encyclopedia. Second edition, vol.04, 218

28 Thomas Carson, Joann Cerrito, eds., The New Catholic Encyclopedia. Second edition, vol.04, 219.
29 Paus dalam ensiklik ini menggemakan kembali ajaran St. Agustinus dan pendahulunya, Paus Leo XIII, mengenai "bonum matrimonium". Paus menegaskan martabat perkawinan kristiani. Perkawinan kristiani bukan hanya institusi manusiwi melainkan juga institusi ilahi (Casti Connubii, no.5). Hubungan seksual suami isteri muncul dari persetujuan bebas mereka. Dengan tindakan dari kehendak bebas mereka, masing-masing menyerahkan diri mereka kepada pasangannya (Casti Connubii, no.6). Kesepakatan yang sudah dibuat oleh pasangan dalam peneguhan perkawinan tidak dapat ditarik kembali. Perkawinan kristiani sangatlah agung dan penuh dengan berkat Allah karena melalui perkawinan itu manusia mengambil bagian dalam karya Allah sendiri (Casti Connubii, no.9).

30 Robert McClory, 1995, Turning Point. The Inside Story of Papal Birth Control Commission, and How Humanae Vitae Changed the Life of Patty Crowley and the Future of the Church, Crossroad, New York, ix.

31 John F. Kippley, 1976, Birth Control and the Marriage Covenant, The liturgical Press, Collegeville, Minnesota, xxvii.

32 Paus Yohanes Paulus II, Anjuran Apostolik "Familiaris Consortio", no. 14; Dokumen Konsili Vatikan II, Konstitusi Pastoral "Gaudium et Spes" tentang Gereja di Dunia Dewasa Ini, art. 50.

33 Franz Magnis-Suseno, 1987, Etika Dasar. Masalah-masalah Pokok Filsafat Moral, Kanisius, Yogyakarta, 45.

${ }^{34}$ Franz Magnis-Suseno, Etika Dasar. Masalah-masalah Pokok Filsafat Moral, 71.

35 William Chang, OFMCap, Pengantar Teologi Moral, 18.

36 Kevin J, O'Neil, CSsR dan Peter Black CSsR, 2003, The Essential Moral Handbook. A Guide to Catholic Living,A Redemptorist Publications, 120.

37 K. Bertens, 2013, Etika, edisi revisi, Kanisius, Yogyakarta, 10-11.

\section{DAFTAR RUJUKAN}

Congregation for the Doctrine of the Faith, 2003, Considerations Regarding Proposals to Give Legal Recognition to Unions between Homosexual Persons.

Bertens, K., 2013, Etika, edisi revisi, Kanisius, Yogyakarta. 
Carson,Thomas dan Joann Cerrito, (eds)., 2003, The New Catholic Encyclopedia. Second edition, vol.13, Gale, Washington D.C, USA.

Chang, OFMCap., William, 2001, Pengantar Teologi Moral, Kanisius, Yogyakarta

Groenen OFM, C., 1993, Perkawinan Sakramental. Anthropologi dan Sejarah Teologi, Sistematik, Spiritualitas, Pastoral, Kanisius, Yogyakarta.

Kippley, John F., 1976, Birth Control and the Marriage Covenant, The Liturgical Press, Collegeville, Minnesota.

Konferensi Waligereja Indonesia, 2011, Pedoman Pastoral Keluarga, Obor, Jakarta.

Lacoste., Jean Yves (Ed.), 2005, Encyclopedia of Christian Theology. Vol.1, Routledge, New York, London

Lawler, M. 1993, Marriage and Sacrament: A Theology of Christian Marriage, Glazier Books, Minnesota.
Magnis-Suseno, Franz, 1987, Etika Dasar. Masalah-masalah Pokok Filsafat Moral, Kanisius, Yogyakarta.

McClory, Robert, 1995, Turning Point. The Inside Story of Papal Birth Control Commission, and How Humanae Vitae Changed the Life of Patty Crowley and the Future of the Church, Crossroad, New York.

Noonan, Jr., John T., 1966, Contraception. A History of Its Treatment by the Catholic Theologian and Canonist, The Belknap Press of Harvard University Press, Massachusetts.

O’Neil, CSsR., Kevin J, dan Peter Black CSsR., 2003, The Essential Moral Handbook. A Guide to Catholic Living, A Redemptorist Publications.

Purwa Hadiwardoyo MSF, Al., 1988, Perkawinan dalam Tradisi Katolik, Kanisius, Yogyakarta.

Rubiyatmoko., Pr, Robertus

2011, Perkawinan Katolik menurut Kitab Hukum Kanonik. Kanisius: Yogyakarta.

2001, Hukum Perkawinan kanonik, Diktat Kuliah, FTW, Yogyakarta. 